\title{
INVESTIGATION OF ENERGY RECOVERY FROM MUNICIPAL SOLID WASTE: A CASE STUDY OF AL- KARAK CITY / JORDAN
}

\author{
Maryam AL-HAJAYA ${ }^{1}$, Salah H. ALJBOUR ${ }^{2, *}$, Husam AL-HAMAIEDEH ${ }^{3}$, Mahmoud \\ ABUZAID $^{1}$, Tayel EL-HASAN ${ }^{4}$, Safwat HEMIDAT ${ }^{5}$, Abdallah NASSOUR ${ }^{5}$ \\ ${ }^{1}$ Renewable Energy Program, Mechanical Engineering Department, Mutah University, $61710 \mathrm{Al}-$ \\ Karak, Jordan. \\ ${ }^{2}$ Chemical Engineering Department, Mutah University, 61710 Al-Karak, Jordan. \\ ${ }^{3}$ Civil and Environmental Engineering Department, Mutah University, 61710 Al-Karak, Jordan. \\ ${ }^{4}$ Chemistry Department, Mutah University, 61710 Al-Karak, Jordan. \\ ${ }^{5}$ Department of Waste and Resource Management, Faculty of Agricultural and Environmental \\ Sciences, University of Rostock, 18051 Rostock, Germany. \\ corresponding author: saljbour@yahoo.com
}

\section{Abstract}

Municipal solid waste (MSW) from Al-Karak city is monitored and characterized. The MSW is sorted into 14 different waste categories. In addition, the MSW is separated into several size fractions, followed by sorting and characterization. The average daily production rate of waste is 61.5 ton/day. The MSW generated per capita is estimated to be $0.55 \mathrm{~kg} / \mathrm{c}$ capita/day. The main input MSW comprised a modest proportion of organic content $38.8 \%$. Other combustible fractions are present in significant proportions, allowing the waste to be utilized for energy recovery. Refuse-derived fuels (RDFs) may be made from waste fractions $>100 \mathrm{~mm}$ and $50-100 \mathrm{~mm}$.
\end{abstract}

Keywords:

Municipal solid waste; Waste screening; Waste characterization; Physico-chemical properties; RDF.

\section{Introduction}

Jordan is witnessing a steady increase in the amount of waste due to the large population growth, the influx of refugees, and economic, commercial and agricultural expansion. The amount of municipal solid waste (MSW) increased from 2.077 million tons/yr in 2014 to 3.466 million tons/yr in $2018[1,2]$. The increasing amount of solid waste (SW) imposes a burden on the infrastructure administrated by the municipalities and the joint service councils and increases the financial costs allocated to dealing with the collection and transportation of SW [3].

Proper management of SW necessitates monitoring and quantifying the daily generation rate of the waste and identifying carefully its sources. In addition, the various waste components and their percentages must be identified. The availability of such data will help decision-makers in the municipalities to develop appropriate plans for optimal handling of waste in a way that ensures sustainability, preserves the environment, and reduces the financial costs of the waste management process.

Instead of disposing of waste to landfills, which most of them lack proper engineering and sanitary design, other options can be more beneficial through separating part of the waste and utilizing that for reuse, recycle or recovery of materials or energy [3].

Jordan relies greatly on imported fossil fuels to meet its energy needs, which constitutes a great burden on the national economy. Therefore, Jordan is moving towards relying on a mixture of energy sources to ensure a state of economic stability and to ensure energy security. Using waste as a source of energy will contribute to achieving these strategic goals and contribute to mitigating the problem of dealing with waste. In fact, the government of Jordan is planning to raise renewable energy contribution in total energy mix. Energy generation in a range of $30-50 \mathrm{MW}$ is expected to be produced from biomass recourses [4]. 
Energy can be recovered from waste through biological conversion methods such as fermentation and anaerobic digestion processes [5-8]. Energy can be also recovered from waste through thermal conversion methods such as pyrolysis [9], gasification [10,11] and incineration.

MSWis characterized by the presence of high percentage of organic matter and the consequent increase in water content, thereby, making direct burning of MSW ineffective. If the mixed MSW is screened, a fraction with high heat content can be obtained that can be used in various thermal processes. Refuse-derived fuel (RDF) is a reclaimed solid fuel that can be used as a substitute for traditional fossil fuels in industry such as in the cement production industry or combined heat and power plants[12]. The remaining parts of the screening process contain a high percentage of organic matter, which can be subjected to anaerobic digestion to produce biogas.

In Jordan, the feasibility of MSW utilization based on their composition, water content, and particle size fractions, has not been investigated adequately. Therefore, it is essential to undertake studies which involve the collection of informative data on waste composition that is hauled to disposal sites, which could provide information to national waste management authorities for decision making; hence, eliminate the confusion in the minds of investors who may want to do business or services in the waste management sector.

The aim of the present study is to generate a comprehensive data on the MSW composition based on its particle size fractions for use in planning and implementation of relevant waste management technologies in Jordan.

\section{Materials and methods}

\subsection{Study area}

Al-Karak Governorate is located in the south region of Jordan, about 140 kilometers to the south of Amman. It is divided into 10 municipalities, which vary between urban, rural and commercial districts. According to the Jordan National Census, the population of the Al-Karak Governorate in 2019 was 350000 [13]. The population of municipalities according to census results is given in Table 1.

Table 1: The population of districts according to census results 2019.

\begin{tabular}{|c|c|}
\hline District & Population \\
\hline Greater Karak & 112060 \\
\hline Ayy & 9010 \\
\hline Mutah and Mazar & 74352 \\
\hline Sheehan & 23820 \\
\hline Talal Aljadedah & 8690 \\
\hline Abdulah Bin Ruaha & 18580 \\
\hline Mu'ab Aljadedah & 30798 \\
\hline Aghwar Janoobiyah & 60650 \\
\hline Qatraneh & 7812 \\
\hline El-Soltani & 4228 \\
\hline Governorate total & 350000 \\
\hline
\end{tabular}

As in other Jordanian cities, the municipalities and Joint Services Council in Al-Karak are daily responsible for municipal cleaning, collection of waste, disposal of waste generated from households and markets and the management of the landfill. There is one landfill in Al-Karak Governorate (Allajjoun landfill).

The study area was restricted to the Greater Karak Municiplitaly (GKM), Fig. 1, where the municipal solid waste is collected from 15 districts. These districts are: Zaid Bin Al-Harithah, Al-Karak, Wadi Al-Karak, Al-Hiwiyah and Al-Talajah, Al-Marj, Zahhoom, Al-Jadidah, Al-Thanyah, Manshiat Abu Hammour, Adr, Al-Shihabiyah, Al-Waysiyyah and Rakin, Al-Ghwair, Batir, and Al-Adnaniyah. 


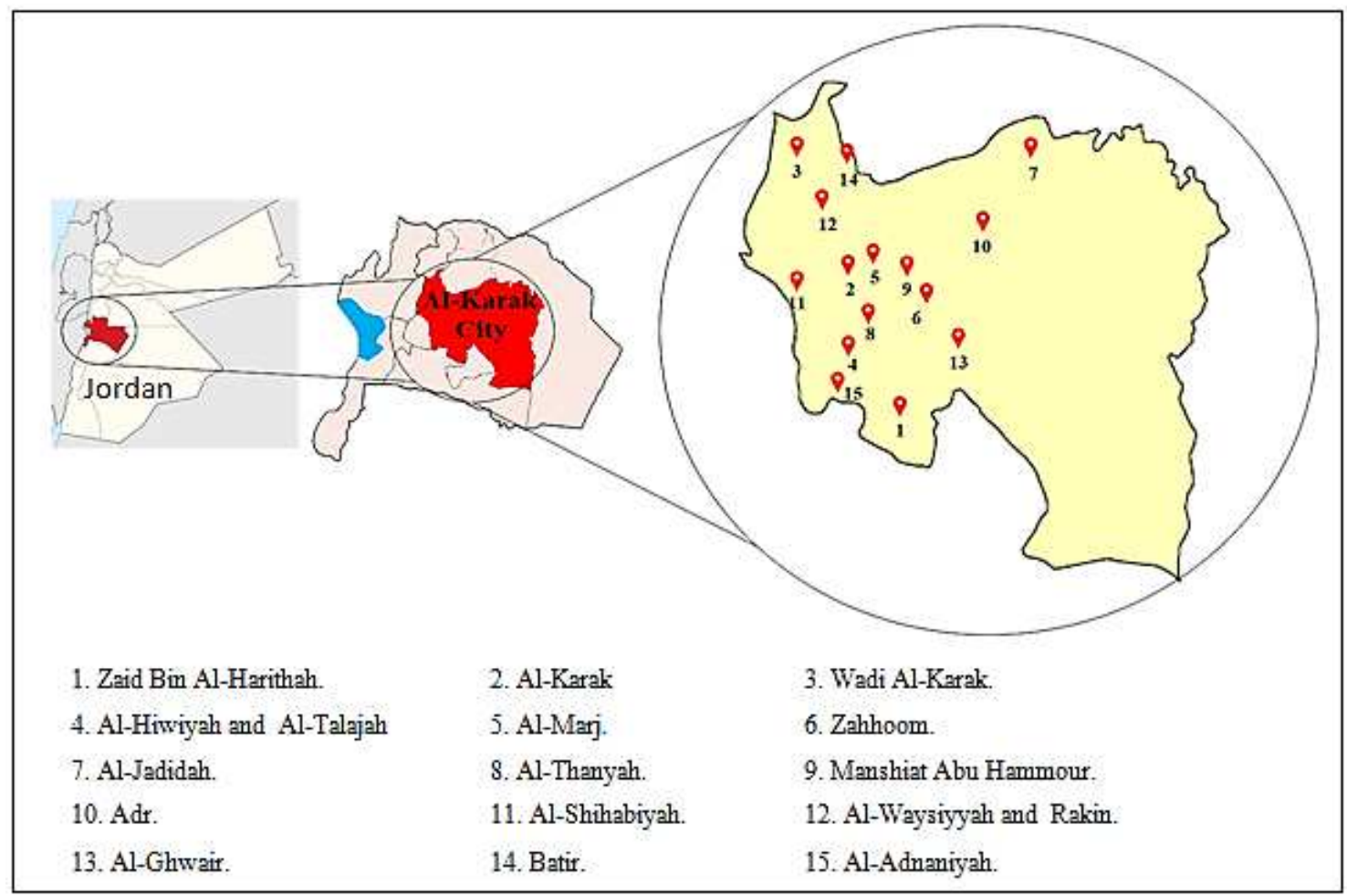

Fig. 1: Study area.

\subsection{MSW monitoring and quantification}

Al-Lajjoun landfill was monitored over three days with the assistance of staffs from the Joint Services Council and the GKM. At first, all trucks carrying the MSW from the 15 districts in GKM were weighed before and after unloading the waste by means of a weighbridge truck scale. In each day, the MSW from the 15 districts are unloaded in a special area assigned by the Joint Services Council to avoid mixing the waste with MSW coming from other municipalities. The waste bags were manually opened and shredded by knives then a loader thoroughly mixed all the waste. The multi quartering and coning procedure is used to produce a representative MSW sample for each day. Since completely mixing the contents with the loader, the collected waste is divided into successive quarters. After that, the samples are coned and quartered several times until they are around $1 \%$ of the original waste amount. Fig. 2 show the steps followed during piling, mixing and quartering the waste.

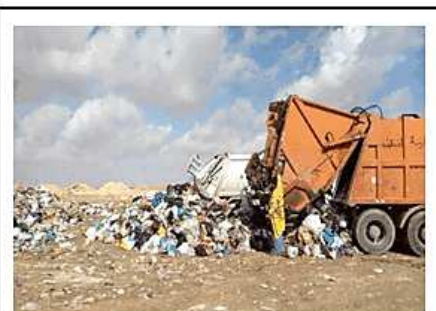

Receiving of MSW

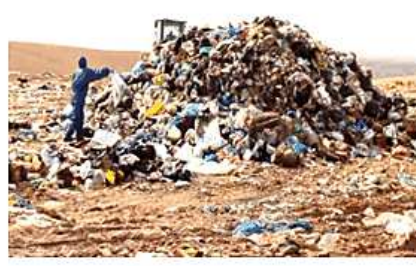

Piling of MSW

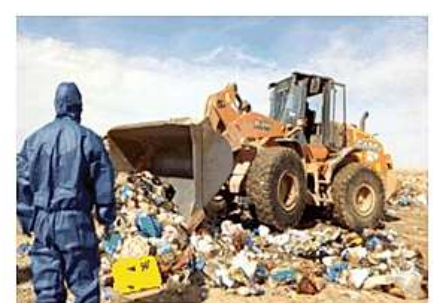

Mixing and Quartering

Fig. 2: Monitoring of MSW at Al-lajjoun landfill.

\subsection{MSW screening and sorting}

The representative waste sample "main input MSW" was screened by an electro-mechanical screening unit. This unit has three different sizes (square opening) that can categorize the waste based on the size in the form of fraction of:

- more than $100 \mathrm{~mm}$,

- between $50 \mathrm{~mm}$ and $100 \mathrm{~mm}$,

- between $10 \mathrm{~mm}$ and $50 \mathrm{~mm}$,

- less than $10 \mathrm{~mm}$. 
Fig. 3 shows the adopted methodology in screening the MSW samples.

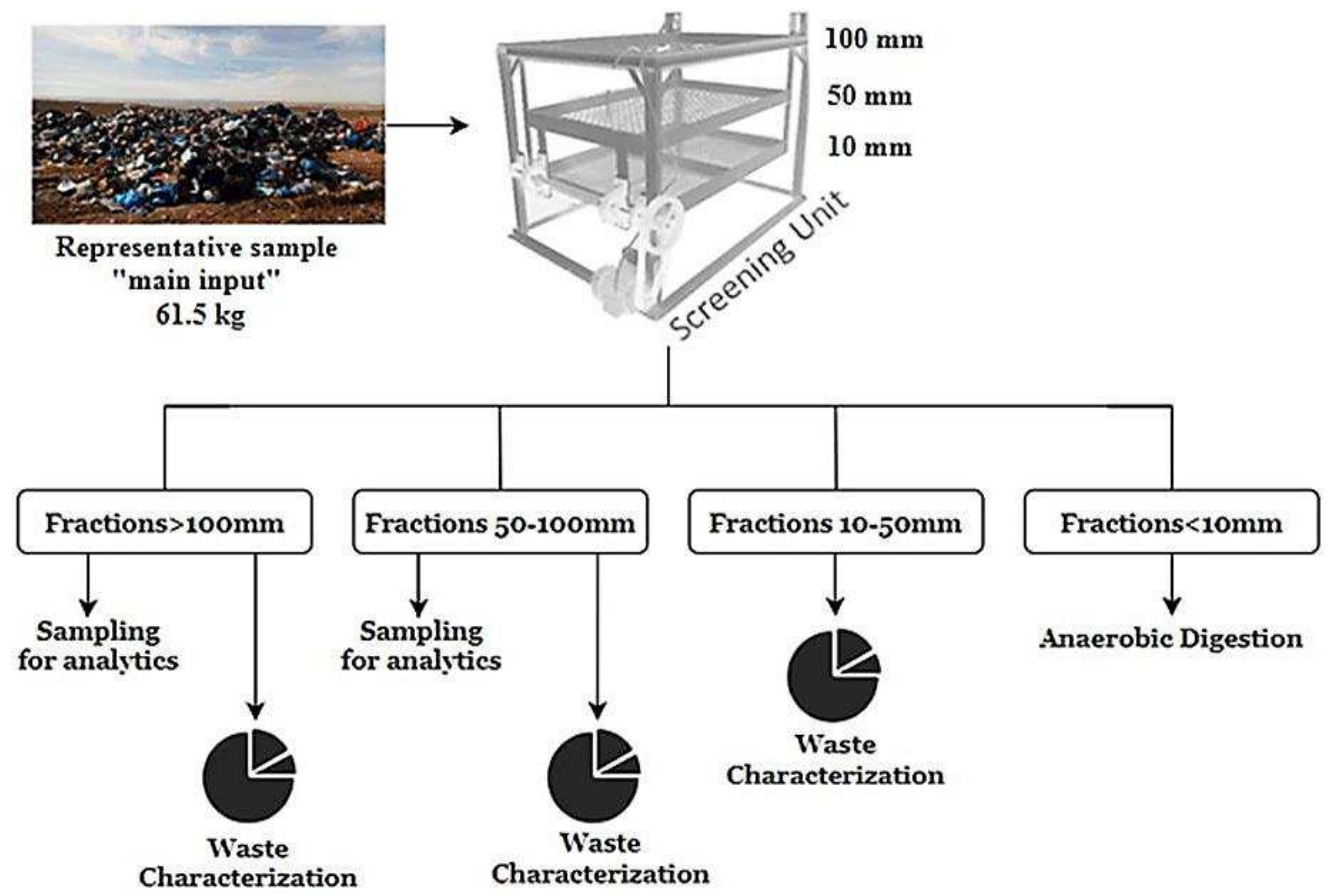

Fig. 3: The adopted methodology.

The waste on each fraction was weighted by electronic balance. Each waste fraction was placed on a clean area, and then sorted manually into 14 categories by seven persons. Table 2 shows the sorting fractions identified in this study and examples of waste for each fraction.

The organic fraction consists of waste such as food waste, garden waste, spoiled food, kitchen waste, etc. The other fraction comprised waste such as: plastic, paper, cardboard, glass, textile, hygienic products, metals, compound material, electronic goods, and others. Plastics were further classified into plastic films and 3D plastic. Metals were divided into ferrous and non-ferrous.

Table 2: Categories of waste.

\begin{tabular}{|c|c|c|}
\hline No. & Sorting fractions & Examples \\
\hline 1 & Organic waste & food waste, garden waste, agricultural waste, food, coffee and tea filters, kitchen waste \\
\hline 2 & Paper & newspaper, magazine, office paper, computer paper,, writing paper, envelopes \\
\hline 3 & Cardboard & carton, boxes \\
\hline 4 & Glass & bottles, fruit and vegetables, jars for chocolate, drinking bottles, windows, composite glass \\
\hline 5 & Textile & clothes, covers, curtains and handbags \\
\hline 6 & Plastic film & plastic bags, nylon, freezer bags, labels packaging films \\
\hline 7 & Plastic 3D & tin cans and bi-metal cans, magnetic drink and food cans \\
\hline 8 & Ferrous & non-magnetic drink and foods cans, other non-magnetic metals, Aluminum cans and foil \\
\hline 9 & Non-ferrous & tissue paper, sanitary pads, bandages \\
\hline 10 & Hygienic products & any material contains two or more substance like shaving razors, belts, toys \\
\hline 11 & Compound material & electrical and electronic items \\
\hline 12 & Electronic goods & undefined material \\
\hline 13 & Others & screened materials (mainly organic) \\
\hline 14 & Fines $<10$ mm &
\end{tabular}

\subsection{MSW characterization}

The main input waste, waste fraction > $100 \mathrm{~mm}$, waste fraction $100-50 \mathrm{~mm}$, and waste fraction $50-10 \mathrm{~mm}$ were subjected to physical and chemical characterization. At first, representative samples for each stream were carefully prepared following standard sampling procedure. Samples are 
shredded into $10 \mathrm{~mm}$ size, then again shredded to $1 \mathrm{~mm}$ size to meet the needs of small-scale laboratory testing. The standard methods followed in the analysis of samples are summarized in Table 3. Each analysis is conducted three times [14], and the reported results in this study represent the average values.

Table 3: Standard test methods for analytics.

\begin{tabular}{|c|c|c|c|}
\hline Analysis & Target & Unit & Method \\
\hline \multirow{4}{*}{ Proximate analysis } & Moisture content, $M C$ & \multirow{4}{*}{ [\%] } & \multirow{4}{*}{ ASTM D5142 } \\
\hline & Volatile matter, VM & & \\
\hline & Ash content, $A C$ & & \\
\hline & Fixed carbon, $F C$ & & \\
\hline \multirow{6}{*}{ Ultimate analysis } & $C$ & \multirow{6}{*}{ [\%] } & \multirow{6}{*}{ EN 15104:2011 } \\
\hline & $S$ & & \\
\hline & $H$ & & \\
\hline & $O$ & & \\
\hline & $N$ & & \\
\hline & Ash & & \\
\hline Calorific value & $C V$ & {$[\mathrm{MJ} / \mathrm{kg}]$} & DIN EN 51900-1 \& 51900-2 \\
\hline \multirow{6}{*}{ Heavy metals content } & $C d$ & \multirow{6}{*}{ [ppm] } & \multirow{6}{*}{ ASTM D7112 } \\
\hline & As & & \\
\hline & $\mathrm{Cr}$ & & \\
\hline & $\mathrm{Hg}$ & & \\
\hline & $\mathrm{Ni}$ & & \\
\hline & $Z n$ & & \\
\hline Chlorine content & $\mathrm{Cl}$ & {$[\%]$} & EN 15408 \\
\hline
\end{tabular}

\section{Results and discussion}

\subsection{MSW generation rate}

Table 4 shows the daily quantities of MSW of Al-Karak districts that arrived to the Al-Lajjoun landfill in three days.

Table 4: MSW generation rate in GKM.

\begin{tabular}{|c|c|c|c|c|c|}
\hline No. & District & 27 Jan [ton] & 28 Jan [ton] & 29 Jan [ton] & Average \\
\hline 1 & Zaid Bin Al-Harithaharea & 6.000 & 4.700 & 2.900 & 4.533 \\
\hline 2 & Al-Karak area & 4.440 & 11.840 & 5.500 & 7.260 \\
\hline 3 & Wadi Al-Karak area & 3.000 & 3.780 & 3.200 & 3.327 \\
\hline 4 & Al-Hiwiyah / Al-Talajah area & 3.000 & 5.040 & 2.700 & 3.580 \\
\hline 5 & Al-Marj area & 5.800 & 2.920 & 2.600 & 3.773 \\
\hline 6 & Zahhoom area & 2.000 & 2.360 & 2.100 & 2.153 \\
\hline 7 & Al-Jadidah area & 3.000 & 0.000 & 2.500 & 1.833 \\
\hline 8 & Al-Thanya area & 4.100 & 6.240 & 9.860 & 6.733 \\
\hline 9 & Manshiat Abu Hammour & 5.000 & 6.520 & 6.200 & 5.907 \\
\hline 10 & Adr area & 3.200 & 3.560 & 2.300 & 3.020 \\
\hline 11 & Al-Shihabiyah area & 2.700 & 4.400 & 2.300 & 3.133 \\
\hline 13 & Al-Waysiyyah-Rakin area & 4.600 & 6.660 & 6.400 & 5.887 \\
\hline 13 & Al-Ghwair area & 4.400 & 0.000 & 4.100 & 2.833 \\
\hline 14 & Batir area & 3.100 & 2.800 & 0.000 & 1.967 \\
\hline 15 & Al-Adnaniyah area & 8.000 & 0.000 & 8.680 & 5.560 \\
\hline & Total & 62.340 & 60.820 & 61.340 & 61.500 \\
\hline
\end{tabular}


The average daily production rate of waste in GKM is 61.50 ton/day. The average daily production rate of MSW in Al-Karak Governorate is 308 ton/day [2]. Therefore, the GKM contributes approximately $20 \%$ of the total MSW that sent to Al-Lajjoun landfill.

The MSW generated per capita in GKM is estimated to be $0.55 \mathrm{~kg} /$ capita/day (based on a population of 112060 and waste generation of 61.50 ton/day). This value is lower than the value reported for the Al-Karak Governorate which is $0.88 \mathrm{~kg} /$ capita/day. Fig. 4 shows waste distribution among districts in GKM.

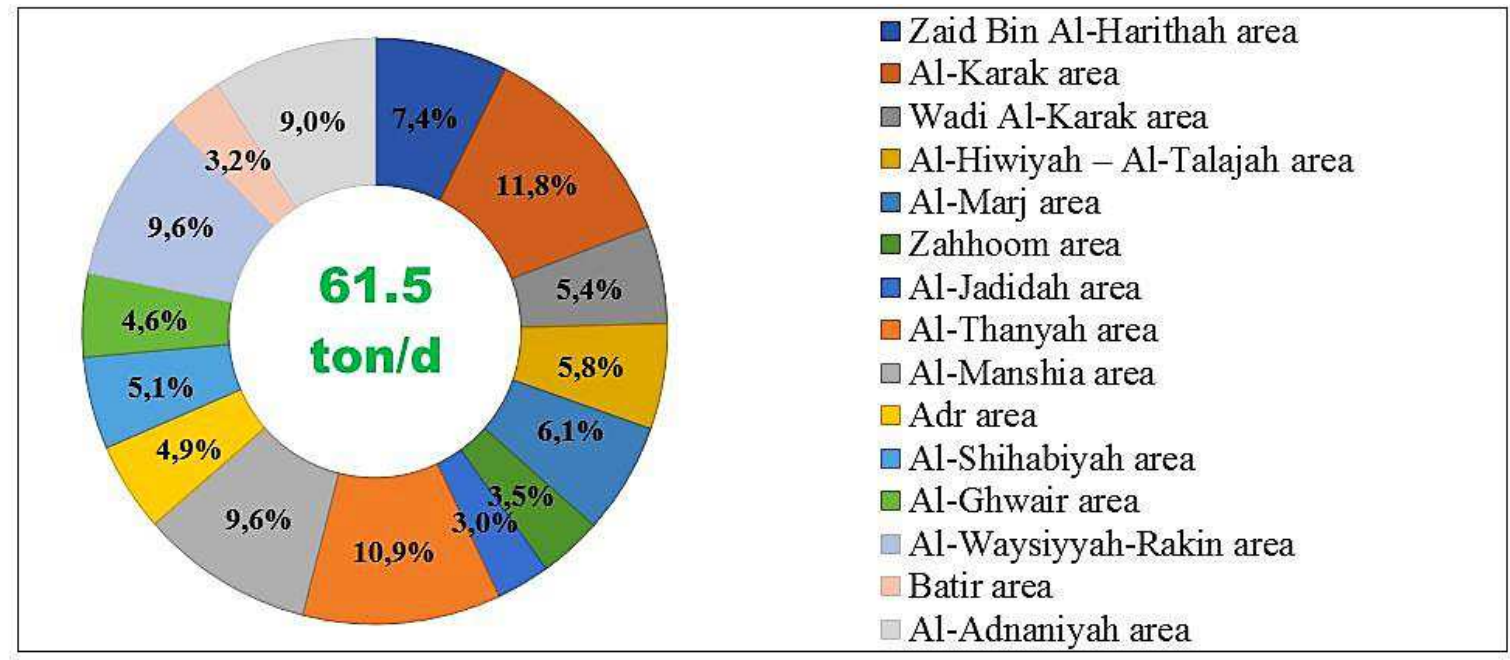

Fig. 4: Waste distribution among districts in GKM.

The highest portion is generated within the Al-Karak area $11.8 \%$. Al-Karak area is considered the city center with a population of 35613 [13]. The area comprises urban and rural areas, hospitals, and the main markets. On the other hand, Al-Jadidah area contributed the lowest percentage of waste share $3.0 \%$. Al-Jadidah area is considered a rural area, and the waste is collected every two days.

\subsection{Main input MSW fractions}

Waste characterization was based on the "Methodology for the Analysis of Solid Waste" of the European Commission (European Commission, 2004). The main fresh input MSW was sorted manually into 14 waste categories, Table 5 .

Table 5: Main input MSW fractions.

\begin{tabular}{|c|c|c|}
\hline No. & Waste category & Fraction wt [\%] \\
\hline 1 & Organic waste & 25.2 \\
\hline 2 & Paper & 3.8 \\
\hline 3 & Cardboard & 10.8 \\
\hline 4 & Glass & 1.1 \\
\hline 5 & Textile & 4.5 \\
\hline 6 & Plastic film & 12.4 \\
\hline 7 & Plastic 3D & 6.3 \\
\hline 8 & Ferrous & 1.9 \\
\hline 9 & Non-ferrous & 2.7 \\
\hline 10 & Hygienic products & 15.5 \\
\hline 11 & Compound material & 0.9 \\
\hline 12 & Electric products & 0.6 \\
\hline 13 & Others & 0.7 \\
\hline 14 & Fines < 10 mm & 13.6 \\
\hline
\end{tabular}


The results showed that the main input MSW is strongly dominated by organic fraction. Accordingly, the total organic fraction in the MSW is $38.8 \%$, which is lower than the organic fraction reported for MSW in other Jordanian cities. For example, Hemidat et al. [12] reported $55.1 \%$ organic fraction in the MSW from Amman city. Younes et al. [15] reported $48.9 \%$ organic fraction in the MSW from Zarqa city. Batareseh et al. [16] reported $55.5 \%$ organic fraction in the MSW from Aqaba city. The low organic fraction in MSW from the GKM might be attributed to source-separation of this waste fraction from the other waste fractions. People in the GKM utilize the organic fraction of MSW for animal and poultry foddering especially spent vegetables, fruit and bread.

The other main MSW fractions in the GKM are plastics $16.7 \%$, hygienic products $15.5 \%$, and paper and cardboard $14.6 \%$. Higher fractions of paper and cardboard, and plastics are noticed in AlKarak compared to Amman. The fractions of paper and cardboard, and plastics in Amman city are 11 and $9 \%$ respectively. The high percentage of these waste fractions in Al-Karak compared to Amman might be attributed to limited availability of recycling centers for these fractions in Al-Karak. In addition, these waste fractions are picked up in different districts in Amman by informal sector prior to collection and disposal to landfills. In the GKM, there is one factory for recycling paper and cardboard, which located in the Al-Hiwiyah area.

From the sorting analysis it was assumed that about $80 \%$ of the fine fraction $<10 \mathrm{~mm}$ was organic material.

\subsection{MSW size distribution}

A screen unit was used to identify the size distribution of the fresh MSW, Table 6. In addition, waste composition for each size fraction was identified.

Table 6: MSW size distribution and waste composition for each size fraction.

\begin{tabular}{|c|c|c|c|c|c|}
\hline \multirow{2}{*}{ No. } & \multirow{2}{*}{ Waste category } & \multicolumn{4}{|c|}{ Percentage } \\
\hline & & $>100 \mathrm{~mm}$ & $50-100 \mathrm{~mm}$ & $10-50 \mathrm{~mm}$ & $<10 \mathrm{~mm}$ \\
\hline 1 & Organic waste & $2.9 \%$ & $18.6 \%$ & $80.2 \%$ & $100.0 \%$ \\
\hline 2 & Paper & $10.0 \%$ & $1.5 \%$ & $0.5 \%$ & $0.0 \%$ \\
\hline 3 & Cardboard & $23.3 \%$ & $9.7 \%$ & $1.8 \%$ & $0.0 \%$ \\
\hline 4 & Glass & $0.0 \%$ & $2.6 \%$ & $1.1 \%$ & $0.0 \%$ \\
\hline 5 & Textile & $12.1 \%$ & $2.3 \%$ & $0.3 \%$ & $0.0 \%$ \\
\hline 6 & Plastic film & $29.5 \%$ & $9.1 \%$ & $0.6 \%$ & $0.0 \%$ \\
\hline 7 & Plastic 3D & $10.9 \%$ & $7.5 \%$ & $1.8 \%$ & $0.0 \%$ \\
\hline 8 & Ferrous & $2.4 \%$ & $2.0 \%$ & $1.9 \%$ & $0.0 \%$ \\
\hline 9 & Non-ferrous & $2.6 \%$ & $4.6 \%$ & $1.7 \%$ & $0.0 \%$ \\
\hline 10 & Hygienic products & $3.5 \%$ & $38.4 \%$ & $9.6 \%$ & $0.0 \%$ \\
\hline 11 & Compound material & $1.8 \%$ & $0.7 \%$ & $0.4 \%$ & $0.0 \%$ \\
\hline 12 & Electric products & $1.1 \%$ & $0.8 \%$ & $0.0 \%$ & $0.0 \%$ \\
\hline 13 & Others & $0.0 \%$ & $2.3 \%$ & $0.0 \%$ & $0.0 \%$ \\
\hline 14 & Fines $<10 \mathrm{~mm}$ & $0.0 \%$ & $0.0 \%$ & $0.0 \%$ & - \\
\hline \multicolumn{2}{|c|}{ Percentage size distribution } & $31.6 \%$ & $32.0 \%$ & $22.8 \%$ & $13.6 \%$ \\
\hline
\end{tabular}

The results revealed that $31.6 \%$ of the MSW was characterized by a size larger than $100 \mathrm{~mm}$, $32.0 \%$ was characterized by a size in the range of $50-100 \mathrm{~mm}, 22.8 \%$ was characterized by a size in the range of $10-50 \mathrm{~mm}$, and $13.6 \%$ was characterized by a size smaller than $10 \mathrm{~mm}$. Many literatures classified MSW based on the size distribution of the waste. For instance, Hemidat et al. [12] screened MSW and found that approximately $30 \%$ of the overall MSW screened could be retrieved as high fraction waste sizes $>100$ and $>150 \mathrm{~mm}$, while $10 \%$ of the waste had sizes less than $10 \mathrm{~mm}$. Sakri et al. [17] categorized the MSW samples into four groups based on particle size: $>100,80-100$, $60-80$, and less than $60 \mathrm{~mm}$. The majority of the input MSW, according to the researchers, was less than $60 \mathrm{~mm}$, which accounted for about $43 \%$ of the total MSW. The coarse fractions of $80-100 \mathrm{~mm}$ and $>100 \mathrm{~mm}$ made up 17 and $32 \%$ of the overall input MSW respectively, while the medium fractions of $60-80 \mathrm{~mm}$ made up $8 \%$. The reported sizes in literature are different due to differences in 
the objective of the screening step for the final-end-application of waste whether to be used for energy and material recovery (RDF, biogas, composting).

The waste fraction $10-50 \mathrm{~mm}$ comprised mainly of organic waste $80.2 \%$. Similarly, the fine waste fraction $<10 \mathrm{~mm}$ was dominated by organic constituents. It is proposed that these waste fractions to be utilized as main or co-substrate for biogas production via anaerobic digestion. On the other hand, the percentages of paper, cardboard, textile, plastic film, and plastic 3D in the waste fraction $>100 \mathrm{~mm}$ are the highest compared with other fractions. These waste categories enhance the calorific value of this fraction, thereby, making it suitable for RDF production. Ferrous and non-ferrous products are almost in the same range in all waste fractions. The total amount of metals was found in the range of $3.6-6.6 \%$. Waste fraction $50-100 \mathrm{~mm}$ comprised the highest percentage of hygienic products $38.4 \%$.

Reza et al. [18] reported potential RDF production from MSW for the years 2015 and 2020 at a yield of 52.8 and $39.9 \%$ respectively for Metro Vancouver Waste Management. Gallardo et al. [19] produced RDF from MSW with a yield of $43.1 \%$. Hemidat et al. [12] reported a $39 \%$ RDF yield obtained from screening MSW at a size $>80 \mathrm{~mm}$. In this study, potential RDF production from screening MSW at size fractions > $80 \mathrm{~mm}$ and $50-100 \mathrm{~mm}$ can be achieved at yields 31.6 and $32 \%$ respectively.

\subsection{Physical and chemical characteristics of MSW and RDFs}

Physci-chemical analysis was carried out for the MSW in the form of fractions of $>100 \mathrm{~mm}$ (RDF-1) and 50 - $100 \mathrm{~mm}$ (RDF-2). The heating value, proximate analysis, ultimate analysis, chlorine content and heavy metal concentrations are examined in order to identify the produced RDF's quality, Table 7.

The results of the proximate analysis indicate that the screening step has effectively reduced the moisture content of waste. The presence of high percentage of organic content in waste is expected to increase the moisture content. The main input MSW has low heating value $5.99 \mathrm{MJ} / \mathrm{kg}$ compared to 13.45 and $11.86 \mathrm{MJ} / \mathrm{kg}$ for RDF-1 and RDF-2 respectively. The low heating value of the main input MSW is attributed to the high organic fraction content. Kara et al. [20] reported that the heating value of RDF is $14.64 \mathrm{MJ} / \mathrm{kg}$ and $25 \%$ moisture content. Hemidat et al. [12] produced RDF from MSW with heating value of $15.58 \mathrm{MJ} / \mathrm{kg}$ and $25.5 \%$ moisture content.

Table 7: Proximate analysis and heating values of MSW and RDFs.

\begin{tabular}{|c|c|c|c|c|c|c|}
\hline & & & Unit & Main input MSW & MSW > 100 mm RDF-1 & MSW 50 - 100 mm RDF-2 \\
\hline \multirow{7}{*}{$\begin{array}{c}\text { Proximate } \\
\text { analysis }\end{array}$} & \multirow{4}{*}{ Wet basis } & $M C$ & [\%] & 43.2 & 12.4 & 23.8 \\
\hline & & $V M$ & [\%] & 38.0 & 72.0 & 54.4 \\
\hline & & $A C$ & [\%] & 15.4 & 5.2 & 15.1 \\
\hline & & $F C$ & {$[\%]$} & 3.4 & 10.4 & 6.7 \\
\hline & \multirow{3}{*}{ Dry basis } & $V M$ & [\%] & 66.9 & 82.2 & 71.4 \\
\hline & & $A C$ & [\%] & 27.1 & 5.9 & 19.8 \\
\hline & & $F C$ & [\%] & 6.0 & 11.9 & 8.8 \\
\hline \multirow{2}{*}{\multicolumn{2}{|c|}{ Heating value $(H V)$}} & $H H V^{*}$ & {$[\mathrm{MJ} / \mathrm{kg}]$} & 7.39 & 23.75 & 19.55 \\
\hline & & $L H H^{* *}$ & {$[\mathrm{MJ} / \mathrm{kg}]$} & 5.99 & 13.45 & 11.86 \\
\hline \multicolumn{7}{|c|}{${ }^{*}$ Higher heating value, ${ }^{* *}$ Lower heating value } \\
\hline
\end{tabular}

The ash content for the input MSW decreased from 27.1 to 5.9 and 19.8 for RDF-1 and RDF-2 respectively. Zhao et al. [20] reported RDF with a range of ash content 6.3 and $12.5 \%$, whereas Sprenger [22] reported RDF with higher values of ash content $19-39 \%$.

The volatile matter content for the input MSW increased from 66.9 to 82.2 and $71.4 \%$ for RDF1 and RDF-2 respectively. Kara et al., [20] characterized RDF with volatile matter content around $81.60 \%$. Kimambo and Subramanian [23] characterized RDF with volatile matter content around $86 \%$.

The fixed carbon content for the input MSW increased from 6to 11.9 and $8.8 \%$ for RDF-1 and RDF-2 respectively. Kimambo and Subramanian [23] reported fixed carbon content for RDF in the range from 4.6 to $9.2 \%$. However, Azam et al. [24] reported fixed carbon content for MSW and RDF as 7.2 and $4.7 \%$ respectively. 
Due to the fact that the characteristic of RDF is greatly influenced by the ultimate analysis, the latter was carried out for the RDFs and the results compared with ultimate analysis of coal material, Table 8.

Table 8: Ultimate analysis and chlorine content of RDFs and coal (dry basis, wt [\%]).

\begin{tabular}{|c|c|c|c|c|}
\hline & RDF-1 (this study) & RDF-2 (this study) & RDF [24] & Coal [25] \\
\hline$N$ & 0.64 & 0.80 & 0.81 & 1.26 \\
\hline$H$ & 8.40 & 6.70 & 8 & 5.50 \\
\hline$O$ & 21.80 & 24.80 & 34 & 31.48 \\
\hline$C$ & 57.50 & 47.50 & 58 & 58.02 \\
\hline$S$ & 0.07 & 0.15 & 0.1 & 0.21 \\
\hline Chlorine & 0.39 & 0.31 & 0.49 & \\
\hline
\end{tabular}

The ultimate analysis results indicate that the carbon content in RDF-1, $57.50 \%$ is very close to the values reported for coal $58.02 \%$, while RDF-2 has relatively low carbon content $47.50 \%$. Elements that cause harmful gaseous emissions such as nitrogen and sulfur have lower content in both RDF-1 and RDF-2 compared to that for coal. These findings indicate that the produced RDFs are good substitutes for coal from environmental perspectives. The hydrogen content for RDF-1 and RDF2 are 8.40 and $6.70 \%$ respectively, which are slightly higher than those reported for coal. On the other hand, the oxygen content for both RDFs is smaller than that for coal. Infiesta et al. [25] reported an ultimate analysis for RDF produced from MSW with values that are close to those reported in this study.

Chlorine content in RDFs is an important quality indicator for the potential use of RDFs in wasteto-energy plants; it causes high-temperature corrosion and poor performance [27]. Prior to use, it is essential to investigate the chlorine content in the produced RDF in order to avoid expensive chlorinerelated problems during utilization. Following the European Standard (EN 15408) for the determination of chlorine content in the produced RDFs, the average chlorine content for both RDF-1 and RDF-2 were 0.39 and $0.31 \%$ respectively. It has been reported that the maximum acceptable limit for chlorine in RDF is $0.9 \%$ [28]. Accordingly, the produced RDFs in this study possessed chlorine content within the acceptable limit.

In terms of heavy metal concentrations, RDFs from GKM showed a wide variety of heavy metal concentrations, as seen in Table 9. The heavy metal concentrations in RDFs produced at GKM are in accordance and sometimes lower than those values set by Europe's standard for RDFs [18]. Heavy metal concentrations are also smaller than those found in Amman city [12].

Table 9: Heavy metals concentration in the produced RDFs [mg/kg].

\begin{tabular}{|c|c|c|c|c|}
\hline & \multicolumn{2}{|c|}{ Greater Karak Municipality [this study] } & Amman [12] & Standard limits [18] \\
\hline & RDF-1 & RDF-2 & RDF & \\
\hline$A s$ & 0.87 & 0.98 & 0.99 & 10 \\
\hline$P b$ & 59 & 51 & N/A & 100 \\
\hline$C d$ & 0.78 & 1.1 & 2.95 & 5 \\
\hline$C r$ & 62 & 44 & 66.00 & 200 \\
\hline $\mathrm{Ni}$ & 14 & 19 & 58.50 & 200 \\
\hline $\mathrm{Zn}$ & 150 & 260 & 270 & 500 \\
\hline $\mathrm{Hg}$ & $<0.03$ & $<0.03$ & $<0.03$ & 1 \\
\hline
\end{tabular}

\section{Conclusions}

The experimental research was conducted in Greater Al-Karak Municipality (GKM) in order to generate a comprehensive data on the MSW composition based on its fractions particle sizes for use in planning and implementation of relevant waste management technologies in Jordan.

The research work began by obtaining representative sample of mixed MSW generated from the city of Karak at Al-lajjoun landfill. A screening unit was then used to categorize the input mixed waste according to its particle size in different fractions. Waste composition was identified based on the "Methodology for the Analysis of Solid Waste" of the European Commission. The MSW was 
divided into 14 primary categories. Sampling and Laboratory analysis were carried out to identify physico-chemical properties. RDF quality was examined and compared with the values set by some European standards.

The results showed that $31.6 \%$ of the MSW could be recovered as a large fraction $>100 \mathrm{~mm}$, $32.0 \%, 50-100 \mathrm{~mm}, 22.8 \%, 10-50 \mathrm{~mm}$, and $13.6 \%,<10 \mathrm{~mm}$. Accordingly, there is high potential for utilizing of the waste fractions of sizes $50-100 \mathrm{~mm}$ in waste to energy applications (refuse-derived fuel (RDF)). While, for the large fraction > 100, the waste included $2.9 \%$ organics, and about $85.0 \%$ combustible material respectively, which are considered as RDF.

The calorific value of unprocessed MSW was found to be $6.00 \mathrm{MJ} / \mathrm{Kg}$. The calorific value of the RDF produced from the pilot project ranged from 11.86 to $13.45 \mathrm{MJ} / \mathrm{kg}$, which made it suitable as a fuel. The ash content of the RDF produced appeared to have a low range between $5.9 \%$ and $19.8 \%$. Chlorine and heavy metals contents were found to be within the acceptable limits.

The experimental research in Al-Karak City proved that RDF from MSW could be a strategic component of an integrated waste management system in order to achieve the recycling and reduction targets for combustible materials going to landfill.

\section{Acknowledgement}

This research is accomplished as a contribution to the Waste to Positive Energy $(\mathrm{Wt}(\mathrm{P}) \mathrm{E})$ project in Jordan. The project is supported and funded by GIZ and with the participation of three German universities (University of Rostock, TU Hamburg and TU Dresden) and four Jordanian universities (Jordan University of Science and Technology, Mutah University, University of Jordan and German-Jordanian University). Authors are grateful for the staff of the GKM (Eng. Sajeda Al-Rahaifeh and Mr. Mohammad Al-Majali) and the Joint Services Council in Al-Karak for their unlimited support and assistance to accomplish this research.

\section{References}

[1] SWEEP-NET, Country report on the solid waste management in JORDAN. 2014.

[2] DEPARTMENT OF STATISTICS, Statistical Yearbook of Jordan 2019. Department of Statistics, Jordan, 2019.

[3] AL-NAWAISEH, A. R. - ALJBOUR, S. H. - AL-HAMAIEDEH, H. - EL-HASAN, T. - HEMIDAT, S. NASSOUR, A.: Composting of Organic Waste: Sustainable Alternative Solution for Solid Waste Management in Al-Karak Governorate/Jordan. Jordan Journal of Civil Engineering, Vol. 15, 2021, pp. 363-377.

[4] AL-HAMAMRE, Z. - SAIDAN, M. - HARARAH, M. - RAWAJFEH, K. - ALKHASAWNEH, H. E. - ALSHANNAG, M.: Wastes and biomass materials as sustainable-renewable energy resources for Jordan. Renewable and Sustainable Energy Reviews, Vol. 67, 2017, pp. 295-314.

[5] KUMAR, A. - SAMADDER, S. R.: Performance evaluation of anaerobic digestion technology for energy recovery from organic fraction of municipal solid waste: A review. Energy, Vol. 197, 2020, p. 117253

[6] MOHAN, S. V. Waste to renewable energy: a sustainable and green approach towards production of biohydrogen by acidogenic fermentation. Sustainable biotechnology, Springer 2010, pp. 129164.

[7] ALJBOUR, S. H. - EL-HASAN, T. - AL-HAMIEDEH, H. - HAYEK, B. - ABU-SAMHADANEH, K.: Anaerobic co-digestion of domestic sewage sludge and food waste for biogas production: $A$ decentralized integrated management of sludge in Jordan. Journal of Chemical Technology and Metallurgy, Vol. 56, 2021, pp. 1030-1038.

[8] ALJBOUR, S. H. - AL-HAMAIEDEH, H. - EL-HASAN, T. - HAYEK, B. O. - ABU-SAMHADANEH, K. - AL-MOMANY, S. - ABURAWAA, A.: Anaerobic co-digestion of domestic sewage sludge with food waste: incorporating food waste as a co-substrate under semi-continuous operation. Journal of Ecological Engineering, Vol. 22, 2021, pp. 1-10.

[9] ALJBOUR, S. H.: Catalytic pyrolysis of olive cake and domestic waste for biofuel production. Energy Sources, Part A. Recovery, Utilization, and Environmental Effects, Vol. 40, 2018, pp. 27852791.

[10] ALJBOUR, S. H. - KAWAMOTO, K.: Bench-scale gasification of cedar wood-Part I: Effect of operational conditions on product gas characteristics. Chemosphere, Vol. 90, 2013, pp. 14951500.

[11] ALJBOUR, S. H. - KAWAMOTO, K.: Bench-scale gasification of cedar wood-Part II: Effect of operational conditions on contaminant release. Chemosphere, Vol. 90, 2013, pp. 1501-1507. 
[12] HEMIDAT, S. - SAIDAN, M. - AL-ZU'BI, S. - IRSHIDAT, M. - NASSOUR, A. - NELLES, M.: Potential utilization of RDF as an alternative fuel to be used in cement industry in Jordan. Sustainability, Vol. 11, 2019, pp. 5819.

[13] DEPARTMENT OF STATISTICS, Estimated Population of the Kingdom by Municipality and Sex, at End-year 2019. Department of Statisitics, Jordan, 2019.

[14] MULAY, B. N. - REDDY, K. R.: Study of Biofilter Planted with Basil for Removal of Ammonia in Aquaponic Water. Civil and Environmental Engineering, Vol. 17, Iss.1, 2021, pp. 242-251.

[15] YOUNES, M. K. - NOPIAH, Z. M. - NADI, B. - BASRI, N. E. A. - BASRI, H. - MOHAMMED, F. M. SHATANAWI, K.: Investigation of solid waste characterization, composition and generation using management of environmental systems in Zarqa, Jordan. Asian Journal of Chemistry, Vol. 25, 2013, p. 9523.

[16] BATARSEH, E. - HARARAH, M. A. - HADDAD, A.: Analysis of Refuse Derived Fuel Utilization from Aqaba Municipal Solid Waste. Jordan Journal of Civil Engineering, Vol. 12, 2018, pp. 245253.

[17] SAKRI, A. - AOUABED, A. - NASSOUR, A. - NELLES, M.: Refuse-derived fuel potential production for co-combustion in the cement industry in Algeria. Waste Management and Research, Vol. 2021, p. $0734242 X 20982277$.

[18] REZA, B. - SOLTANI, A. - RUPARATHNA, R. - SADIQ, R. - HEWAGE, K.: Environmental and economic aspects of production and utilization of RDF as alternative fuel in cement plants: A case study of Metro Vancouver Waste Management. Resources Conservation and Recycling, Vol. 81, 2013, pp. 105-114.

[19] GALlARDO, A. - CARLOS, M. - BOVEA, M. - COLOMER, F. J. - ALBARRÁN, F.: Analysis of refuse-derived fuel from the municipal solid waste reject fraction and its compliance with quality standards. Journal of Cleaner Production, Vol. 83, 2014, pp. 118-125.

[20] KARA, M. - GÜNAY, E. - TABAK, Y. - DURGUT, U. - YILDIZ, Ş. - ENC, V.: Development of refuse derived fuel for cement factories in Turkey. Combustion Science and Technology, Vol. 183, 2010, pp. 203-219.

[21] ZHAO, L. - GIANNIS, A. - LAM, W. Y. - LIN, S. X. - YIN, K. - YUAN, G. A. - WANG, J. Y.: Characterization of Singapore RDF resources and analysis of their heating value. Sustainable Environment Research, Vol. 26, 2016, pp. 51-54.

[22] SPRENGER, C. J.: Classification and Densification of Municipal Solid Waste for Biofuels Applications. Chemical and Biological Engineering, University of Saskatchewan, Canada, 2017.

[23] KIMAMBO, O. N. - SUBRAMANIAN, P.: Energy efficient refuse derived fuel (RDF) from municipal solid waste rejects: a case for Coimbatore. International Journal of Environment, Vol. 3, 2014, pp. 205-215.

[24] AZAM, M. - JAHROMY, S. S. - RAZA, W. - JORDAN, C. - HARASEK, M. - WINTER, F.: Comparison of the combustion characteristics and kinetic study of coal, municipal solid waste, and refuse-derived fuel: Model-fitting methods. Energy Science and Engineering, Vol. 7, 2019, pp. 2646-2657.

[25] INFIESTA, L. R. - FERREIRA, C. R. N. - TROVÓ, A. G. - BORGES, V. L. - CARVALHO, S. R.: Design of an industrial solid waste processing line to produce refuse-derived fuel. Journal of Environmental Management, Vol. 236, 2019, pp. 715-719.

[26] KHAIRIL - IRWANSYAH - EDHY, H. S. - RIZAL, S., Fundamental study on the carbonization characteristics of low rank coal under low temperature and its application on traditional blacksmith. Advanced Materials Research, Trans Tech Publ, 2012, pp. 615-618.

[27] MA, W. - HOFFMANN, G. - SCHIRMER, M. - CHEN, G. - ROTTER, V. S.: Chlorine characterization and thermal behavior in MSW and RDF. Journal of Hazardous Materials, Vol. 178, 2010, pp. 489-498.

[28] RADA, E. C. - RAGAZZI, M.: RDF/SRF evolution in the MSW sector: Coexistence of BMT and selective collection. International Journal of Sustainable Development and Planning, Vol. 10, 2015, pp. 109-119. 